Linköping studies in science and technology.

Dissertation No. 1790

\title{
Early domestication? Phenotypic alterations of Red Junglefowl selected for divergent fear of humans
}

Beatrix Agnvall

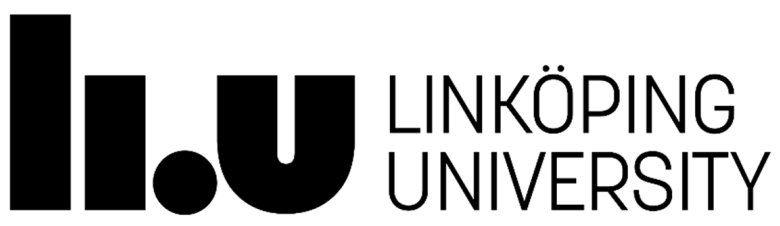

IFM Biology

Department of Physics, Chemistry and Biology

Linköping University, SE-581 83, Linköping, Sweden

Linköping 2016 
Early domestication? Phenotypic alterations of Red Junglefowl selected for divergent fear of humans

Beatrix Agnvall

Linköping studies in science and technology. Dissertations, No. 1790

ISSN: 0345-7524

ISBN: 978-91-7685-685-7

Front cover: Male and female Red Junglefowl

Photo: Beatrix Agnvall, edited by Ann-Sofie Sundman

Copywright @ Beatrix Agnvall unless otherwise noted

Printed by LiU-Tryck, Linköping, Sweden, 2016 
Till min Pärla och min Skatt, tack för att ni gör mitt liv så mycket mer, av allt. Älskar er till månen och tillbaka

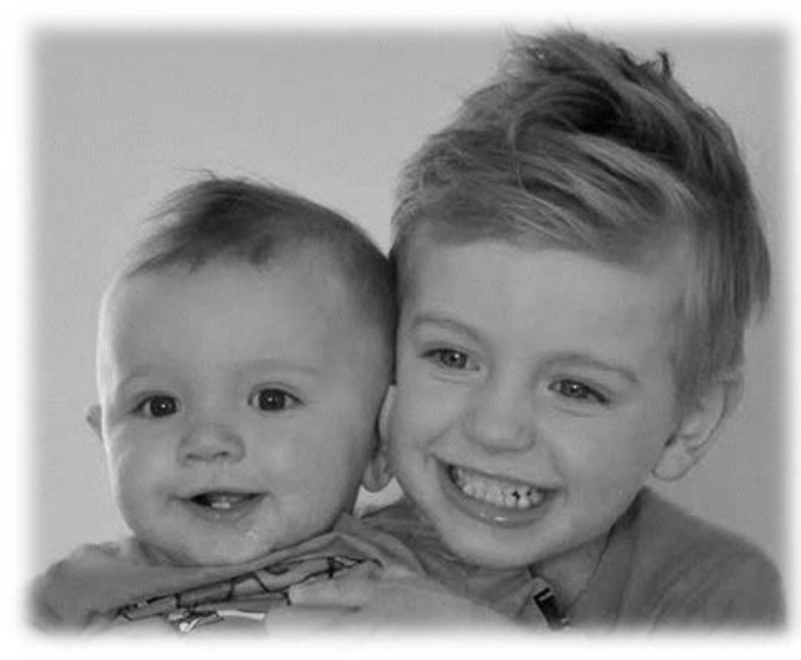

Foto Kenneth Danielsson 



\section{Abstract}

Domestication is the process through which animals adapt to conditions provided by humans. The domesticated phenotype differs from wild ancestors in a number of traits relating to physiology, morphology and behaviour. One of the most striking differences is the animals' fear response towards humans, and reduced fear of humans is assumed to have been an early prerequisite for the success of domestication. The early alterations seen in the domesticated phenotype may be traits developed as a correlated selection response due to tameness rather than selected upon one by one.

This thesis summarizes a project where Red Junglefowl were selected for divergent fear of humans during six generations. In every generation, fear response to human was assessed in a standardized test and, according to fear score, the animals were bred for either high fear of humans (H) or low fear of humans (L). The animals were, above that of the standardized selection test, behaviourally phenotyped in different tests in each generation mainly focusing on fear, exploration and social behaviour. In addition to behaviour, the animals were phenotyped for body weight, egg weight, metabolism, feed intake, plumage condition, blood plasma corticosterone and peripheral serotonin. After culling, vital organs and brains were harvested and weighed.

In paper I, we demonstrated that the selection trait has a significant genetic heritability and is genetically correlated with other behavioural responses associated with fearfulness and exploration. In paper II, we concluded that animals from the L strain had better plumage condition, higher weight, laid larger eggs and also generated larger offspring. Furthermore, when tested in a social dominance test with a limited resource, they received less and performed more aggression regardless of whether the restricted source was edible or not. In paper III, we revealed that animals from the L strain had higher basal metabolic rate as chicks, gained more weight in relation to feed intake and were bolder in a Novel Object test. Furthermore, the L males had higher plasma levels of peripheral serotonin, but the corticosterone after a restraint stress test did not differ. In paper IV and $\mathbf{V}$, we concluded the project by comparing brain and organ weights as well as behaviour of the parental generation (Po) with the fifth selected generation $\left(\mathrm{S}_{5}\right)$. The absolute brain weight as well as the weight specific brain weight were larger in the animals selected on $\mathrm{H}$ than in the L-animals. The relative weight of telencephalon was significantly higher in $\mathrm{H}$ whereas relative weight of cerebellum was significantly lower. Heart, liver, spleen and testes were all relatively heavier in $\mathrm{H}$ animals than in L. Interestingly, the behaviours assessed in Po and $\mathrm{S}_{5}$ seemed to be rather resilient to the selection with only small differences in $\mathrm{S}_{5}$.

To summarize, the selection on divergent tameness in Red Junglefowl has affected several phenotypic traits associated with the domesticated phenotype. The results of this project indicate that tameness in Red Junglefowl could be an underlying factor driving trait modifications towards the domesticated phenotype. 



\section{Populärvetenskaplig sammanfattning}

Den här avhandlingen är ett resultat av ett projekt där vi avlat djur på tamhet för att undersöka egenskapens roll i den tidiga domesticeringen. De domesticerade djur som vi har i vår närhet har alla genomgått en process där de har anpassats för vår miljö. Det skulle kunna liknas vid en snabb evolution, där ett djurs utseende och beteende förändras under en relativt sett kort tid genom avel av människan. Domesticerade djur skiljer sig från sina vilda släktingar på många olika sätt, de kan vara både mindre och större är ursprunget, finnas i olika färgvariationer, ha ändrade kroppsproportioner och de skiljer sig även åt i tröskelvärden för beteende från de vilda djuren. Skillnaderna mellan domesticerade djur och ursprunget är förvånansvärt lika mellan djurarter och man brukar kalla detta för den domesticerade fenotypen.

I det här projektet ville vi se om den domesticerade fenotypen egentligen är en biprodukt som uppkommer om man avlar djur på tamhet, på så sätt skulle rädslan för människor vara en nyckelegenskap för domesticeringen. För att undersöka detta använde vi det röda djungelhönset (RJF) som alla domesticerade höns härstammar ifrån. I sex generationer avlades RJF som antingen hade hög eller låg rädsla för människor. Eftersom vi bara har ett avelskriterium kan vi dra slutsatsen att om dessa djur kommer att skilja sig åt på fler sätt så beror det på korrelerade selektionseffekter. Det vill säga, man avlar på en egenskap och andra egenskaper följer med.

I varje generation har vi utfört beteendetester på djuren som främst varit kopplade till rädsla, utforskande och sociala beteenden. Utöver beteendetesterna har vi undersökt djurens kroppsvikt, äggvikt, metabolism, födointag, fjäderdräkt och tagit blodprov för att mäta kortikosteron och serotonin. När djuren har avlivats har vi vägt hjärnan, hjärtat, levern, mjälten och testiklarna.

Efter sex generationer av selekterad avel hade hönsen i projektet förändrats på olika sätt. Först och främst konstaterade vi att rädslan för människa är möjlig att avla på då den har en signifikant genetisk arvbarhet. De djuren som har en låg rädsla för människor har blivit större, socialt dominanta, lägger större ägg och får större avkomma. Metabolismen har påverkats så att de höns som har låg rädsla för människor har högre metabolism och omsätter även maten mer till tillväxt än de djuren med hög rädsla. Aveln har även påverkat djurens morfologi, de djuren som har hög rädsla för människor och alltså kan anses vara mer som ursprunget har större hjärna, hjärta, lever och mjälte. Många av dessa förändringar som uppkommit redan efter sex generationer korrelerar med de skillnader man ser mellan vilda och domesticerade djur vilket påvisar vikten av egenskapen för domesticeringsprocessen. 



\section{List of publication}

The thesis is based on the following papers, which will be referred to in the text by their Roman numerals (I-IV)

Paper I Heritability and genetic correlations of fear-related behaviour in red junglefowl - possible implications for early domestication B Agnvall, M Jöngren, E Strandberg, P Jensen, PLoS ONE, 7, e35162

Paper II Red Junglefowl (Gallus gallus) selected for low fear of humans are larger, more dominant and producer larger offspring B Agnvall, A Ali, S Olby, P Jensen. Animal, 8 1498-1505.

Paper III Is domestication driven by reduced fear of humans? Boldness, metabolism and serotonin levels in divergently selected red junglefowl (Gallus gallus)

B Agnvall, R Katajamaa, J Altimiras, P Jensen, Biology Letters, 11,7

Paper IV Brain size is reduced by selection for tameness in Red Junglefowl - correlated effects in vital organs

B Agnvall, J Bélteky and P Jensen, Submitted

Paper V Effects of divergent selection for fear of humans on behaviour in Red Junglefowl

B Agnvall, P Jensen, accepted for publication in PLoS ONE 



\section{Contents}

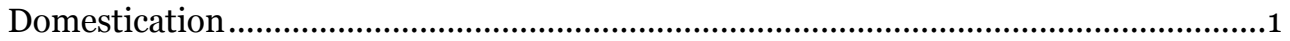

Effects of domestication ..................................................................................... 2

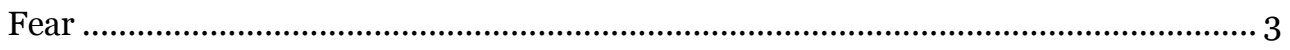

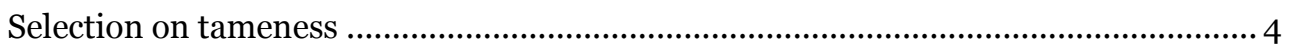

Selection on tameness in silver foxes (Vulpes vulpes) ........................................... 4

Selection on tameness in rats (Rattus norvegicus) ............................................ 5

Selection on tameness in Mink (Neovision vision) ............................................. 5

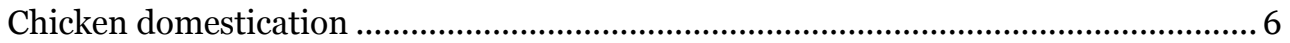

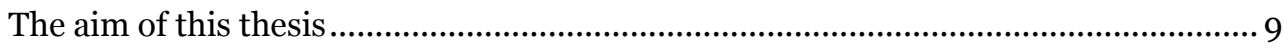

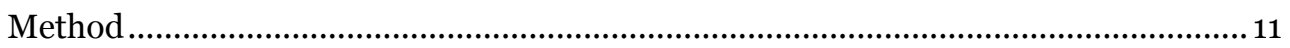

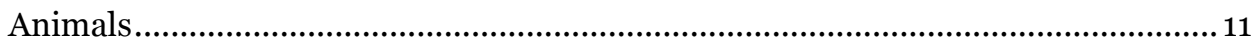

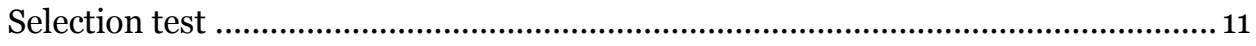

Selection and breeding ..............................................................................12

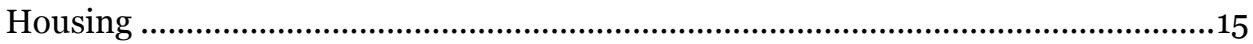

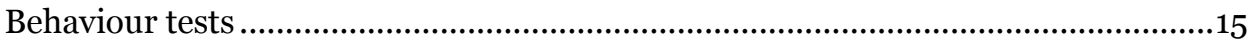

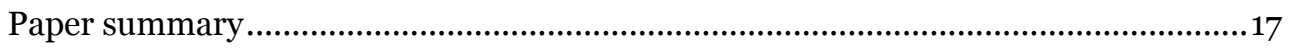

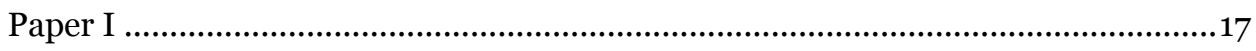

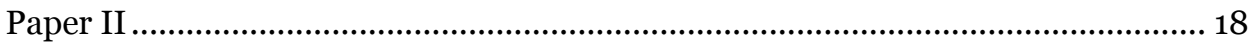

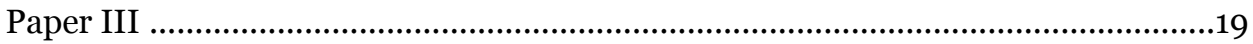

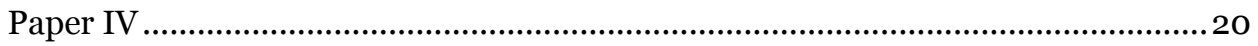

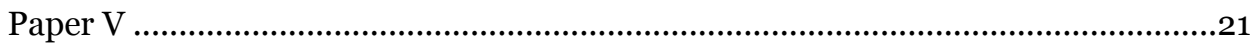

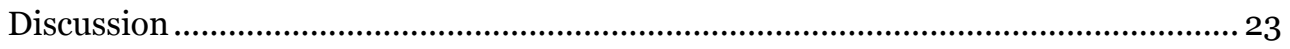

The domestic phenotype ............................................................................... 23

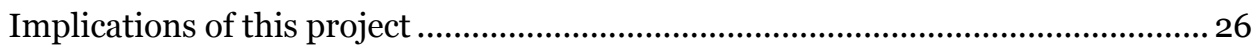

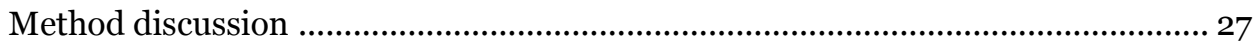

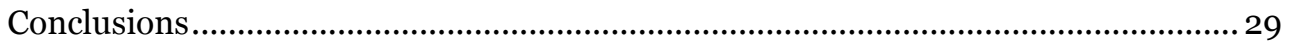

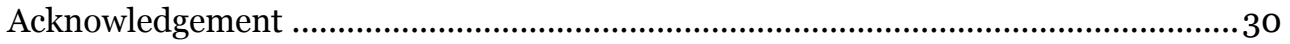

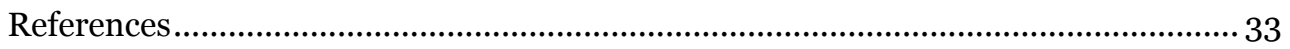





\section{Domestication}

In 1984, Price defined domestication as "that process by which a population of animals becomes adapted to man and to the captive environment by some combination of genetic changes occurring over generations and environmentally induced developmental events during each generation". Domestication can be viewed as an accelerated evolution and a result of conscious breeding for characteristics; it has also resulted in both morphological and behavioural changes (Price 1999). Even though many scientists have defined domestication, it is difficult to do so in a way that conveys all the impact it has had on both humans and animals. Ducos (1989) writes that a satisfactory definition of domestication should mention that the behaviour of not only animals, but also of man has been changed during domestication. To live in an environment surrounded by domesticated animals is something we take for granted. The importance and the impact domesticated animals have had on our lifestyle is extensive and a mankind without domesticated animals is hard to imagine.

It was probably due to the process of domestication, of both animals and plants, that humans started an agricultural lifestyle (Smith 2001). The dog was the first species that became domesticated. Through genetic sequencing, Frantz et al. (2016) revealed that the dog derived from two distinct wolf populations from east and west Eurasia with the dog and the wolf clearly divided from each other 14 ooo years ago, hence before the settlement of humans. Among livestock, sheep (Meadows 2014) and goats (Zeder and Hesse 2000) were probably the first animals to become domesticated around 10 ooo years ago in East Asia, followed by cattle and pigs (Clutton-Brock 1999). Chickens, the focus of this thesis, started the domestication process around 8000 years ago (West and Zhou 1988). The details of this will be discussed later in the thesis. It is not yet clear why humans started to domesticate animals, but it is clear that, in the time span it occurred, people started to become more resident and settled down from the hunter-gatherer lifestyle (Clutton-Brock 1999). Most domesticated species are now used for food production and companionship (Price 1984).

Domestication is affected by genetic changes influenced by inbreeding, genetic drift, artificial selection and natural selection in captivity. Although selection pressure is altered in captivity, the domestication process has to be actively selected for in order to occur (Künzl et al. 2003). The domesticated phenotype refers to the ability the animals have to adapt to the captive environment. Hence, domesticated animals are less sensitive to changes in their environment (Price 1999). Interestingly, only a few species have gone through the process of domestication, and attempts with species not suited for domestication have been documented (Clutton-Brock 1981). The species that have successfully gone through the process of domestication have all some traits in common, e.g., they are highly social animals, have short flight distance to humans, are not specialists in terms of food intake and, in the case of domesticated birds, most are precocial (Diamond 2002). It is not difficult to imagine that animals that possess these characteristics are easy to hold in captivity. Other favourable traits in captivity are high reproduction rates and promiscuous mating. Additionally, having a social hierarchy reduces aggressiveness when several individuals are kept in the same place (Appleby et al. 2004). 


\section{Effects of domestication}

Domesticated animals differ from their wild counterparts in numerous ways that, interestingly, are similar in many aspects between species; this is generally referred to as the domesticated phenotype (Clutton-Brock 1999; Jackson and Diamond 1996; Price 1999) and will be described in the following section.

\section{Behaviour}

Although there are behaviour differences between wild and domestic animals, it is mainly not in the behaviour repertoire, but rather in the threshold for different behaviours (Price 1999). Chickens, for example, selected for high egg production perform the same behaviour repertoire as Red Junglefowl in a stable group situation, but differ on a quantitative level with less wing flapping, waltzing and crowing (Boice 1973; Väisänen et al. 2005). Another difference between the domesticated chickens and the wild type can be seen in their foraging strategy where the wild type performs more contrafreeloading. Contrafreeloading is the term used when an animal uses more energy for the actual search for food than necessary. Possibly, domesticated chickens, selected for high egg production, have higher growth and reproduction investment, which in turn leads to a higher need of food and energy, hence, the decrease in contrafreeloading (Lindqvist et al. 2002; Schütz and Jensen 2001). Moreover, the social life of the domesticated animal differs in many aspects from the social life of the wild ancestor. The domesticated animals are more socially tolerant with groups that are much more dynamic considering group size, regrouping and home ranges compared to the progenitor. In order to cope with this, one could expect that the social behaviour of domesticated animals has altered during the process and that mutations affecting social behaviour have been important during domestication (Jensen and Wright 2014).

\section{Physiology and morphology}

Most domesticated animals have altered their size during early domestication and most common among the species is a decrease in size (Tchernov and Horwitz 1991). However, during the last 100 years, selection on domesticated animals has intensified on traits favourable for production, such as meat, milk and egg yield, and the modern domestic animal is not necessarily smaller in size than the wild ancestor (Emmerson 1997; Oltenacu and Broom 2010; Zuidhof et al. 2014). In addition to alterations in body size, growth, colour and metabolism, reproduction is also affected by domestication (Devlin et al. 2001; Rosenfeld et al. 2015). Domesticated laying chickens, for example, start their egg laying at 18 weeks, about seven weeks earlier than the Red Junglefowl (Schütz et al. 2002).

Another commonly seen alteration in domestic animals is a reduction in brain size. There are numerous examples of domesticated animals of different taxa with a reduction of overall brain weight such as mink (Kruska 1996), sheep (Ebinger 1974), pigs (Plogmann and Kruska 1990) and several avian species including turkeys (Ebinger 
and Röhrs 1994), chickens (Jackson and Diamond 1996), pigeons (Rehkämper et al. 2008) and ducks (Ebinger 1995). The brain is a highly energy demanding organ and in captivity, where challenges to survive and reproduce are different from the wild, a large brain is probably too costly (Diamond 2002). The reduction in brain size may be a result of a trade-off between other energy demanding physiological traits such as reproduction and growth (Isler and van Schaik 2006b). Interestingly, the brain does not seem to be affected by domestication as a homogenous organ but instead some parts are more affected than others. The telencephalon, for example, seems to weigh less in most domesticated species (Kruska 1988a; Kruska 1988b)

A very recent suggestion for a common cause underlying the alterations seen in domesticates is that, along with domestication as an unselected by-product, selection for a reduction in neural crest-derived tissue has occurred that in turn affected neural crest cell (NCC) numbers at their final sites. This ultimately leads to the morphological changes seen in the domesticated phenotype. The deficit of NCC could be produced via three routes: reduced number of original NCC, lesser migratory capabilities of NCC or decreased proliferation of NCC at final sites (Wilkins et al. 2014)

\section{Fear}

Domesticated animals differ in their fear response from the wild ancestors probably due to both unconscious selection and direct selection (Forkman et al. 2007). Boissy (1995) defined fear as a behavioural response to the perception of actual danger. When an animal experiences fear, the defence system activates and glucocorticoids as well as adrenal catecholamine enable a rapid behavioural action by mobilizing available resources (Boissy 1995). Numerous papers of different species (chickens (Campler et al. 2009); finches (Suzuki et al. 2013); sheep (Dwyer 2004); rats (Blanchard et al. 1986)) indicate the same result: the domesticated variant is less fearful than the wild ancestor, which indicates that fear in some context has been an important target during domestication. Although domesticated animals experience limited situations with actual predators, there are several situations in their everyday lives that can elicit fearrelated responses (Hargreaves and Hutson 1990; Wohlt et al. 1994). The behaviour responses to fear vary greatly between and even within species with active defence (attack, threat), active avoidance (flight, escape) or even immobility (freezing) being common responses. The different strategies are probably more or less successful depending on different factors such as level of fear, environment and physical state of the frightened animal. That fear as a concept differs between contexts has been proven both by behavioural observations and by QTL-mapping in different species of wild and domestic animals. In cattle, QTL analysis of two behaviour tests with fear in different contexts, flight from human and social isolation, were investigated. They found no QTL overlaps on these two traits which supports the hypothesis that different genetic factors influence behavioural responses to different situations (Gutierrez-Gil et al. 2008). In sheep, Hazard et al. (2014) found no QTL overlaps for the different behaviour traits tested. Hence, the behavioural responses in domestic sheep to social separation and 
exposure to humans are under polygenic influence. Further, in cattle, there were no correlations between flight from human and novelty, although the flight distances were consistent in different test situations (Gibbons et al. 2009), and wild caught greenfinches (Carduelis chloris) showed no correlation between different tests of fearfulness, although they showed repeatability within tests (Sepp et al. 2014). These examples indicate that fear and fearfulness are driven and motivated by different underlying genetic mechanisms and that the behavioural responses are not necessarily correlated.

\section{Selection on tameness}

One of the most striking differences between a domesticated animal and the wild progenitor is the reduced fear response towards humans. Domesticated animals can more easily be handled by humans compared to the wild type, which instead usually expresses a high fear of humans. It is difficult to determine how the domestication of animals originally started. One possible theory is that animals that stayed close to human settlements were later either caught or allowed to stay in the surroundings and were then eventually bred upon and their offspring were probably less fearful for humans and so on. It is therefore likely that this trait - tameness - was both important and crucial for domestication (Belyaev et al. 1985). With this theory as background, there have been several selection projects on different species such as silver fox (Belyaev et al. 1985), rat (Albert et al. 2008) and mink (Malmkvist and Hansen 2002).

\section{Selection on tameness in silver foxes (Vulpes vulpes)}

The most famous and long-lasting project is the farm-fox experiment started by Dmitry K. Belyaev in Siberia. He selected the foxes strictly on a fear for human test, carefully described in Belyaev et al. (1985), which has been conducted in the same manner for every generation for more than 50 years. His aim was to show that many of the morphological and behavioural differences between domesticated animals and their wild ancestors could originate from only one behaviour trait, fear for humans. The foxes he bred upon had been in captivity for more than 80 years but had retained their wild type of behaviour and strict seasonal rhythm of reproduction (Belyaev and Borodin 1982). One of the first changes accompanying the selection was a decrease in activity of the HPA-axis (Trut et al. 1972). After a few generations, some characteristics of the domesticated phenotype appeared in the selected foxes, such as floppy ears, piebald marks, short tails, curly tails, etc., all similar to the domestic dog. They also differed ontogenetically such that the selected foxes show the first fear response after 9 weeks compared to the wild type that showed it after 6 weeks. This delay in development could be caused by levels of corticosteroid hormone in the plasma being lower in the selected foxes (Belyaev et al. 1985). After 20 selected generations, some of the females also changed their reproduction cycle to twice a year (Belyaev and Borodin 1982), and the selected animals also had higher levels of central serotonin (Popova et 
al. 1991). Kukekova et al. (2008) found a strong principal component that explained more than $48 \%$ of the behaviour variance associated with tame behaviour in the foxes. By QTL mapping, they revealed that this component was associated with a region on chromosome 12. This region, in turn, is homologous to a region on chromosome 5 in dogs that is presumed to be responsible for the early domestication of wolves (Kukekova et al. 2011; vonHoldt et al. 2010).

\section{Selection on tameness in rats (Rattus norvegicus)}

Belyaev and colleagues also selected wild brown rats on either high or low aggressiveness towards a glove. After 8-10 generations, the rats' aggressiveness towards the glove had either increased or decreased depending on selection although the aggression towards conspecifics remained unchanged (Naumenko et al. 1989). After 20 generations, the low aggression rats adrenocortical activity and monoamines in the brain had changed with lower levels of plasma corticosterone and higher mean levels of serotonin (5-HT) in the brain (Naumenko et al. 1989). In an intercross between the tame and the aggressive rats, Albert et al. (2009) identified two significant QTL for tameness. Interestingly, these loci overlap with QTL for adrenal gland weight and for anxiety-related traits which are known to be affected in domesticated animals (Price 1999; Richter 1952).

\section{Selection on tameness in Mink (Neovision vision)}

In a similar selection study done on mink, the behaviour differences between two selected strains have been investigated. The study started in Denmark 1988 where the selection test was based on the approach/avoidance theory. By putting a stick into the cage, the researchers could score if the animal approached the stick (considered as confident) or avoided the stick (considered as fearful). In 1998, 10 years after the selection process started, Malmqvist and Hansen (2002) performed an extensive investigation of behaviour differences between these two strains of mink. They studied the minks in the stick test, Trapezov's hand test, novel object test, social test, novel food test and an x-maze test. The conclusion they could draw from the results was that the strain that reacted fearful to the stick in the selection test also acted more fearful in all the other test situations (Malmkvist and Hansen 2002).

Whether the correlated selection responses seen in these studies are due to genes that can act on more than one trait, pleiotropy, or due to genes that are closely located on the chromosome and may be inherited together, linkage, is not yet fully known. Although it is still an open question if the domesticated phenotype is due to correlated selection responses, i.e. pleiotropy or linkage, or due to active selection on these traits, the farm fox experiment, the selection on wild rats and farmed mink emphasize the importance of the fear of human trait for the early domestication process. 


\section{Chicken domestication}

The domesticated chicken as well as its ancestors belong to the genus Gallus (Junglefowl), which contains four species: 1) Gallus gallus (Red Junglefowl), 2) Gallus sonneratii (Grey Junglefowl), 3) Gallus lafayetii (Ceylon Junglefowl) and 4) Gallus varius (Green Junglefowl) (Al-Nasser et al. 2007). The Red Junglefowl (G. gallus), which lives in field edges, groves, and scrubland in India, China, Java, Malaysia, Indonesia and the Philippines, was believed to be the sole ancestor of the domesticated chicken (Al-Nasser et al. 2007; Collias and Collias 1996; West and Zhou 1988) until 2008 when Eriksson et al (2008) investigated the origin of the yellow skin that is abundant among domesticated chickens. Surprisingly, this trait likely originates from the Grey Junglefowl which means that the domesticated chicken probably originates from a hybrid between the Grey and the Red Junglefowl.

The domestication process started at around 8000 years ago (West and Zhou 1988) in South and Southeast Asia and probably started out simultaneously in different countries in Asia (Liu et al. 2006). The focus of the domestication of the chicken in the beginning was most likely not on their eggs since Red Junglefowl only produce five to six eggs in a breeding season, but rather on cockfighting or religious reasons (Liu et al. 2006; Nicol 2015)

The Red Junglefowl has been behaviourally described in the wild by Collias and Collias (1967) and was found to be a highly fearful bird that is difficult to get sight of. The Red Junglefowl is generally smaller than the domesticated chicken, a female weighs about $800 \mathrm{~g}$ and a male around $1000 \mathrm{~g}$ (Schütz et al. 2002). There is substantial sexual dimorphism with the male larger than the female and more colourful. The female is mostly brown while the male is red on the neck and back and has long black (almost shimmering blue, purple and green) feathers on the tail (Zuk et al. 1990) (Figure 1).

The domesticated chicken is now one of the world's most widespread species and is the main food source in many countries. The total number of chickens in the world is difficult to calculate and even to imagine, but in 2012 nearly 60 billion chickens were killed for meat and 4-5 billion (109) egg laying hens produced over 1 trillion $\left(10^{12}\right)$ eggs (Nicol 2015). This indicates the importance of the chicken as a domesticated species for the human population. 


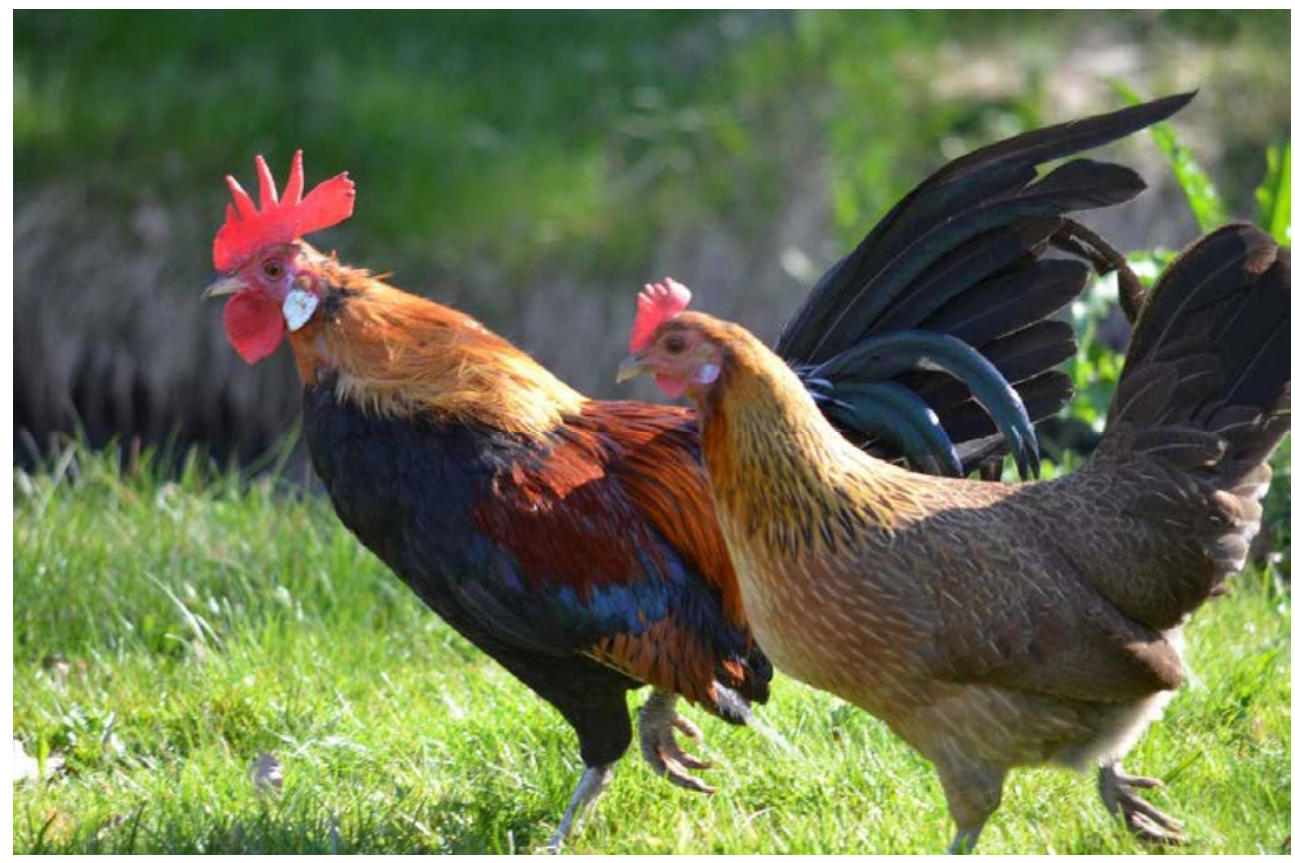

Figure 1. Male and female Red Junglefowl.

Photo: Per Jensen 


\section{The aim of this thesis}

The overall aim of this thesis was to investigate the correlated selection responses in Red Junglefowl selected on divergent fear of humans. In contrast to the farm fox experiment, the chicken has already undergone the domestication process and its differences from the ancestors of the chicken have already been described in numerous papers, a few examples are Abeyesinghe et al. 2009; Andersson et al. 2001; Borowicz and Graves 1986; Campler et al. 2009; Campo et al. 2001; Chase 1982; Clarke and Jones 2001; D'Eath and Dawkins 1996; D'Eath and Stone 1999; Dawkins 1995; de Haas et al. 2013; Eklund and Jensen 2010. The domesticated phenotype mentioned above is highly relevant for the domesticated chicken since they have, among other differences, altered their reproduction capacity (Schütz et al. 2002), growth (Kerje et al. 2003a), colouration (Kerje et al. 2003b) and behaviours such as fear response towards humans (Campler et al. 2009), exploration and foraging strategy (Schütz and Jensen 2001).

In this project, we tested the hypothesis that alterations of domesticated animals from their wild counterparts are correlated selection responses from the animals' fear of human response. In order to test this, we bred Red Junglefowl for six generations solely on divergent fear response in a standardised fear of human test. The animals from every generation were then phenotyped in different behaviour tests, most of them related to fear, but also social behaviour and dominance. The animals were weighed at different ages and organs were harvested at cull. Since the selection focused on fear, corticosterone and peripheral serotonin were assessed in S6 in order to measure differences in the endocrine system. 


\section{Method}

\section{Animals}

The breeding procedure is thoroughly described in Agnvall et al. (2012), but will be repeated here as well for clarity. The animals in this experiment originate from two captive populations that had been held in captivity for more than five generations with a population size of about 70-80 individuals in every generation. The population from Copenhagen Zoo (COP) could range free over an area of 7 ha occasionally experiencing predators and they could also breed freely. The other population from Götala (GOT) was held in a research environment, sex separated and with no natural exposure to predators. The two populations differed significantly in their overall fear level and are thoroughly described in Håkansson and Jensen (2008) and Håkansson and Jensen (2005). In order to maximize the genetic variation in the parental generation (Po), the two populations were crossbred for two generations by first mating 13 pairs of COP females with GOT males (COPxGOT) and 15 pairs of COP males with GOT females (GOTxCOP). In the next generation (Poo) the outbreeding continued with mating 11 pairs of GOTxCOP females with COPxGOT males and 8 pairs of GOTxCOP males with COPxGOT females. The offspring of the second outbred generation (the third outbred generation) constituted the parental generation (Po) of the experiment (Agnvall et al. 2012). The Po was the first generation that was exposed to the selection test (described below) which all the following generations were subjected to and bred upon depending on fear score.

\section{Selection test}

At the age of 12 weeks, the chickens were subjected to the standardized selection test where the fear response to a human was assessed. The test is described in details in (Agnvall et al. 2012), paper I. It was performed in an arena measuring $100 \times 300 \times 210$ $\mathrm{cm}$ with wire mesh roof and walls except for $50 \mathrm{~cm}$ high solid walls at the bottom. The floor of the arena was made of concrete and divided into three equally sized zones, one for every meter and not visible to the chicken (Figure 2).

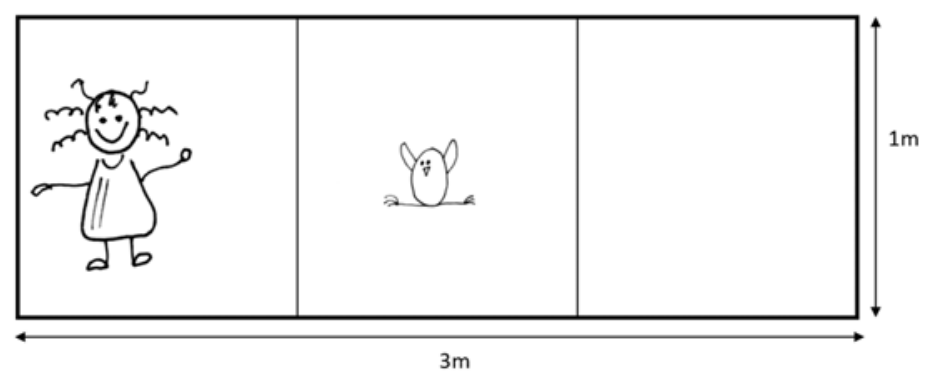

Figure 2 shows a schematic picture of the fear of human arena. The two lines symbolize the zones into which the test person enters every minute. 
The chickens were individually collected in darkness from the home pen by an assistant and given to the test person in darkness. Each chicken was then placed, still in darkness, in the middle of the arena with the test person standing in one short end of the arena. The test started when the light was turned on and the behaviour (according to ethogram, table 1) was scored with one-zero sampling every $10^{\text {th }}$ second. After one minute, the test person moved into the second zone continuing to score the behaviour of the chicken during the subsequent minute. The same procedure was repeated for the next minute and the test ended with the test person attempting to touch the chicken and scoring the behaviour in the same manner. In all, the test proceeded for three minutes. The score ranged from 1 to 5 , where 1 signified a fearless animal and 5 a highly fearful animal. In the end, this was calculated to an average of all the sampling points which then constituted the fear score assigned to the chicken.

Table 1 Selection criteria for the selection test, Fear of human

\section{Fear level Behaviour}

1 Exploring, standing or walking, with short neck.

2 Standing or walking with eyes open and neck stretched. Headflicks and vocalizing 1-5/10 sec.

3 Standing or walking with eyes open and neck stretched. Headflicks and vocalizing 6-15/10 sec.

4 Standing or walking with eyes open and neck stretched. Headflicks and vocalizing $>15 / 10$ sec.

5 Escape attempts and vocalizing loudly alt. the bird is completely still (freeze behaviour)

In order to validate the consistency of the behaviour of the chicken and the interobserver reliability, ten randomly selected chickens from S2 were tested twice and with two different observers. There was a significant correlation between the fear score of the chickens and between the two observers (Agnvall et al. 2012).

\section{Selection and breeding}

Depending on the fear score assigned to the animals in the selection test, the animals of Po were divided into High fear (H), Low fear (L) and Unselected (U, called Intermediate (I) in Agnvall et al. 2012 but was then renamed). The $\mathrm{H}$ and L groups each consisted of $27 \%$ of the chickens with the highest and lowest scores respectively. The U group consisted of the rest of the chickens from the Po generation. Within H, L and $\mathrm{U}$, the animals were mated randomly in the Po generation, 24 pairs of $\mathrm{H}$ and $\mathrm{L}$ and 6 pairs of $\mathrm{U}$. This generated S1, the first selected generation, and, in the same way as Po, they were subjected to the selection test at the age of 12 weeks. To generate S2, the 20 most fearful chickens within $\mathrm{H}$ were mated, the 22 least fearful chickens within $\mathrm{L}$ 
were mated, and random pairs were formed in $\mathrm{U}$, whilst keeping the family origin for every bird under control to minimize inbreeding. The same procedure was repeated for generating $\mathrm{S}_{3}, \mathrm{~S}_{4}$, $\mathrm{S}_{5}$ and finally $\mathrm{S} 6$. For detailed information about every generation, see figure 3. The unselected strains started out by the name "intermediate". We changed that and renamed it to "unselected strain" since the purpose of the strain was not to keep and breed a strain in between High and Low, but to have animals that were not intentionally bred on their fear score. As such, they were bred within the same strain from Po, but selected solely on pedigree and not depending on fear score. 


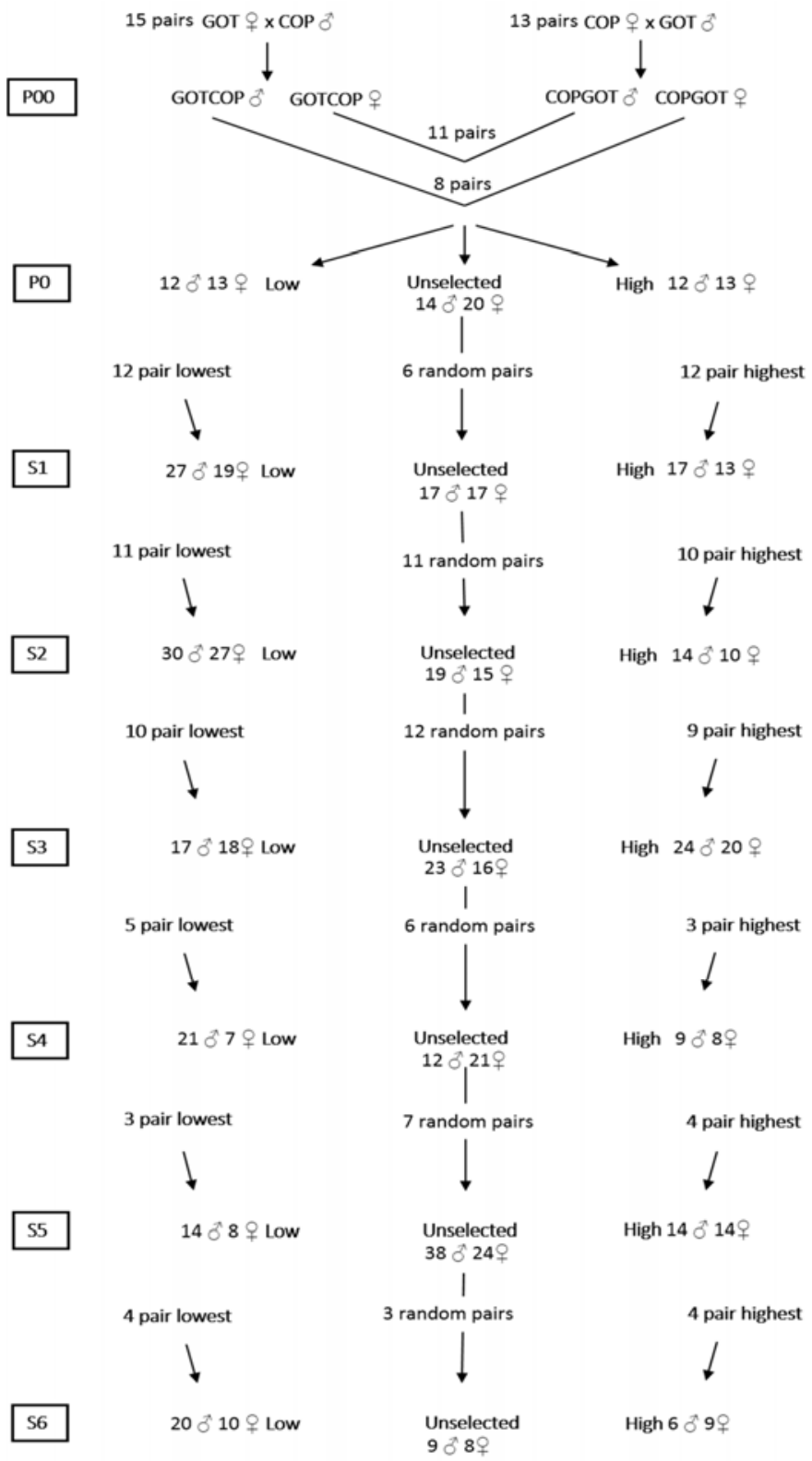

Figure 3 Breeding schedule of the selected birds from P00 and P0, the parentals, to S6, the sixth selected generation. 


\section{Housing}

All the animals were pedigree hatched in family compartments in Marsalles Commercial incubators at $37.7{ }^{\circ} \mathrm{C}, 55 \%$ humidity and with rotation of the eggs every hour in the hatchery Krujit located at Linköping University. Directly after hatching, the chicks were removed from the incubator, weighed, vaccinated against Mareks disease and wing tagged. The chickens were housed together in pens furnished with saw dust, heat lamps during the first weeks, perches, feed and water ad libitum. The pens measured $75 \times 75 \times 180 \mathrm{~cm}$ from start and were then gradually expanded with a maximum size of $225 \times 225 \times 180 \mathrm{~cm}$. At the age of 5 weeks, the chickens were moved to the chicken house, Wood-Gush, located $15 \mathrm{~km}$ from Linköping University where they were housed together until 12 weeks of age when they were sex separated. All the generations from this experiment have been housed in the same two pens, measuring $300^{*} 300^{*} 300 \mathrm{~cm}$, in the chicken house. The pens were furnished with a triplex system with nest boxes, sawdust, perches and feed and water ad libitum. From S4 and onwards the chickens also had access to an outdoor aviary furnished with branches and pallet collar filled with material for dust bathing. The birds were on a $12 \mathrm{~h}$ day $12 \mathrm{~h}$ night cycle.

\section{Behaviour tests}

The behaviour tests used in this experiment can roughly be divided into three areas of interest: measuring fearfulness, social behaviour and explorative behaviour. All the behaviour tests are thoroughly described in papers I and V.

\section{Fear related behaviour tests}

Since we selected the animals on their fear of human level, we started out by measuring different aspects of fearfulness. In the aerial predator (AP) test, the animals were subjected to a predator model suddenly flying over the arena. This test measures both fear in a sudden situation and reactions to a predator. For more information about the test see Agnvall et al. 2012, paper I. The tonic immobility (TI) reaction of a chicken is probably a defence mechanism towards a direct predator attack. This reaction is widely used to measure the fear reaction in chickens (Gallup 1979). In this test, the simulated predator attack is hands on (in the presences of a human) and there are no sudden surprises as in the aerial predator test, thus, these tests complement each other. As mentioned earlier, chickens are highly social animals and social isolation is a potentially fearful situation. In the open field test, the animals' fear reaction to social isolation in an open area is measured; this test is widely used to measure fear and anxiety in different species (Archer 1973). The open field test was done when the chicks were 4 weeks (OF4W) and 16 weeks old (OF16W) in slightly different settings and in different locations.

\section{Social behaviour tests}

As mentioned in the introduction, the social behaviour of the chicken has been altered during domestication, thus, we also wanted to assess and explore any differences due 
to the selection. In a social reinstatement test (SR), the distance moved in the arena and the time spent in the social zone near an unknown conspecific could be a measurement of how stressful the social isolation is for the chicken and hence how social the animal is. In generation S3 (paper II), we measured the overall social behaviour of the chickens in an undisturbed situation in groups of three animals of the same strain and sex. This was followed by a social dominance test with a limited resource in groups of three, but now with one chicken from each strain. Since the test in $\mathrm{S}_{3}$ was done in the presence of a human, we repeated the test in $\mathrm{S}_{4}$, but now with video recording and no direct observation in order to exclude the factor of the animals' different fear level towards humans.

\section{Foraging and exploration test}

Since it was previously known that exploration and feeding strategy have been altered during domestication, we also wanted to include this in our experiment. In the foraging and exploration test, the animals were subjected to different food sources that required more or less energy from the chicken while the chicken obtained more or less energy from the food source. This was done in a social stable environment without social isolation, for details see paper II (Agnvall et al. 2014).

To measure the animals' fear reaction or curiosity towards a novel object, we subjected the chickens to a novel object (a coca cola can), in a safe environment, with no vision of a human being (detaily described in paper III).

\section{Other measurement}

Besides behaviour tests, we also documented body weight, plumage condition, egg weight and harvested organs when the animals were culled. All the six generations were treated almost identically, although some variations were inevitable. 


\section{Paper summary}

\section{Paper I}

\section{Heritability and Genetic Correlations of Fear-Related Behaviour in Red Junglefowl- Possible implications for early domestication}

Agnvall B., Jöngren M., Strandberg E. and Jensen P., 2012. PLoS ONE, 7, e35162.

First and foremost, we needed to estimate the heritability of the selection trait and any possible genetic correlations between this trait and other traits the animals have been tested upon. For the first paper, we used the parental generation (Po) and the first and second selected generations ( $\mathrm{S} 1$ and $\mathrm{S} 2$ ). We hypothesised that groups of birds differing in their fearfulness towards humans would also differ in other behavioural phenotypes and that there would be significant heritabilities associated with the phenotypes as well as significant genetic correlations between various traits. In order to test the hypothesis, all the animals in each generation were, in addition to being weighed at hatching, also exposed to a number of behavioural tests in order to map out the phenotypes of the chickens. Most of the behaviour tests were related to different kinds of fearfulness such as social reinstatement (SR), open field (OF4, OF16), aerial predator (AP) and tonic immobility (TI). The other areas of interest connected to the domesticated phenotype were foraging and exploration strategy, hence we also tested these traits in a foraging and exploration test (FE). Heritability, genetic correlations and breeding values were estimated.

The results from this study revealed that the selection trait had a significant genetic component with a moderate but significant heritability, hence it is possible to select for this trait. The animals' fear of human level also genetically correlated to behavioural responses of which some were associated with fearfulness and others with exploration and foraging. 


\section{Paper II \\ Red Junglefowl (Gallus gallus) selected for low fear of humans are larger, more dominant and produce larger offspring}

Agnvall, B., Ali, A., Olby, S. and Jensen, P. 2014. Animal, 8, 1498-1505.

Since we, in paper I, found a genetic correlation between the fear of human trait and exploration and foraging, we were interested in further investigating this area of research. In paper II, we therefore mainly focused on how social behaviour (SB) and social dominance (SD) in feed and non-feed related situations were affected by the selection. We measured this on animals of the third ( $\left.\mathrm{S}_{3}\right)$ and fourth $\left(\mathrm{S}_{4}\right)$ selected generations. In SB, three animals (same sex and selection) were placed in an arena with free access to feed, water and perches; three groups were tested at the same time. The social behaviour was observed, after $18 \mathrm{~h}$ of habituation, during a $3 \mathrm{~h}$ period with continuous sampling for 5 min periods interspersed by 10 min pauses. The SD test took place immediately after SB finished by moving one animal from each group into selection mixed (but still sex separated) groups of three. In order to measure dominance in $\mathrm{S}_{3}$, we used mealworms as a limited resource and in $\mathrm{S}_{4}$ we added water and a dust bath as limited resources. In $\mathrm{S}_{4}$, the animals were deprived of the resource which they were going to be tested for and the behaviour of the animals was video recorded, not directly observed as in $\mathrm{S}_{3}$, in order to exclude any possible effects of a human in the test situation. In $\mathrm{S}_{3}$, the chickens were also subjected to an exploratory behaviour and sociality test (ES) in order to investigate the animals' propensity to explore a novel arena with known and unknown feed and at the same time maintain social contact with a conspecific of the same selection strain and sex. In addition, we also measured plumage condition, growth, egg weight and weight of offspring as possible indicators of adaption to the environment the animals live in.

To sum up, the results of this study showed that animals selected for low fear of humans performed more aggressive behaviours in SD in all of the three resource situations and were more feed motivated, both in SD and ES. They also had less damaged plumage, which indicates that they were less exposed to feather pecking. Furthermore, they were also larger as adults, laid larger eggs and generated larger offspring than birds selected on high fear of humans. We interpreted this as the animals selected on low fear possibly being better able to cope with the experimental environment in which they had been selected. 


\section{Paper III \\ Is domestication driven by reduced fear of humans? Boldness, metabolism and serotonin levels in divergently selected red junglefowl (Gallus gallus)}

Agnvall B., Katamajaa R., Altimiras J. and Jensen P., 2015, Biology Letters 11, 9.

Since we, both in papers I and II, learned that feeding motivation and weight of offspring, eggs and adults were affected by the selection we wanted to further investigate this. This led us to measure the animals basal metabolic rate (BMR) in S5, using open flow respirometry at the age of five to six weeks. Further, at the age of 1921 weeks, feed intake and boldness were assessed. We measured individual feed intake over 7 days by weighing the feed remains every day. Feed efficiency was assessed by dividing the average weekly growth of each bird between 112 and 200 days by its total feed intake. Finally, when the birds were still in cages, they were subjected to a novel object (NO) test in order to measure the individual boldness of the chickens. The latency for the chicken to approach a novel object with egg as motivator was recorded at 19-21 weeks. Later, in S6 at the age of 28 weeks, we assessed plasma corticosterone before and after a short period of physical restraint. Blood was collected within 3 minutes of human handling, after 10 minutes of restraint (hanging in a fish net) and a third sample was collected 30 minutes after the first blood sample. At 47 weeks of age, we collected blood for peripheral serotonin analysis. Both corticosterone and serotonin were measured with ELISA.

The results from this study revealed that animals selected on low fear of humans had higher BMR as chicks and tended to have higher feed efficiency than animals selected on high fear of humans. The serotonin levels were also higher in low fear (L) males, which perhaps could mediate the BMR and feed efficiency differences. The L birds (particularly females) were also bolder in the NO test, but, interestingly, there were no effects of selection on plasma corticosterone. We expected that animals selected on low fear of humans would have an overall reduced stress and fear response which was supported by the results in NO, but not by the plasma corticosterone. The results from this study support the hypothesis that reduced fear of humans during the early phases of chicken domestication may have caused birds to evolve a phenotypic complex involving increased boldness and a more growth-promoting metabolism. 


\section{Paper IV \\ Brain size is reduced by selection for tameness in Red Junglefowl - correlated effects in vital organs}

Agnvall B., Bélteky J. and Jensen P. Submitted

A well-known phenotypic alteration correlated with domestication is the change in morphology, and especially brain size, of the animals. We were therefore interested in the comparison of brain size and other vital organs between the parental generation (Po) and the fifth selected generation $\left(\mathrm{S}_{5}\right)$. When the birds were 48-54 weeks, we weighed and culled them with rapid decapitation. The brain (divided into four parts referred to as: telencephalon, cerebellum, midbrain and optic lobe), liver, spleen, heart and testicles from the males were collected and weighed. Since the strains differed in body size, relative weights were used for further analysis (except for the absolute brain weight). The weight of the organs and the body weight were analysed within $\mathrm{S}_{5}$ as well as between Po and $\mathrm{S} 5$.

The results from this study showed that the absolute and relative sizes of major organs, particularly the brain, can change as a result of correlated responses to selection for tameness in Red Junglefowl. Animals selected on high fear of humans $\left(\mathrm{S}_{5} \mathrm{H}\right)$ had heavier brains than low fear animals ( $55 \mathrm{~L}$ ). The brain weight also differed from Po to $\mathrm{S}_{5} \mathrm{H}$ in the same direction with $\mathrm{S}_{5} \mathrm{H}$ having a heavier brain. This indicates that domesticated phenotypes may, to some extent, evolve as a correlated effect of reduced fear of humans, a trait that is of central importance for the initial phases of domestication. Furthermore, our results show that modifications of brain size may selectively act on only some brain regions indicating that the correlated effects may possibly be adaptive and affecting specific brain functions. $\mathrm{S}_{5} \mathrm{H}$ had a significantly larger telencephalon than $\mathrm{S}_{5} \mathrm{~L}$ whereas the cerebellum showed the opposite alteration with $\mathrm{S}_{5} \mathrm{~L}$ being larger than $\mathrm{S}_{5} \mathrm{H}$. Optic lobes did not differ within $\mathrm{S}_{5}$, but $\mathrm{S}_{5} \mathrm{~L}$ had significantly smaller optic lobes than Po. The midbrain did not differ within $\mathrm{S}_{5}$ or between $\mathrm{S}_{5}$ and Po. The other collected organs also differed within $\mathrm{S}_{5}$, mainly in the same direction with $\mathrm{S}_{5} \mathrm{H}$ having relatively heavier heart, spleen, liver and testicles. The modifications, both between Po and $\mathrm{S}_{5}$ and within S5, generally go in the direction expected from the domesticated phenotype indicating that tameness may be a driving factor underlying organ size changes. 


\section{Paper V \\ Effects of divergent selection for fear of humans on behaviour in Red Junglefowl}

Agnvall B., Jensen P. Accepted for publication in PLoS ONE

Domesticated animals differ from the progenitor mostly in thresholds of behaviour rather than in the behaviour repertoire as such. In order to discover any behaviour differences as a correlated response from the selection on the divergent fear of human trait, we again tested animals from the fifth selected generation $\left(\mathrm{S}_{5}\right)$ to the parental generation (Po). The birds were tested for social reinstatement tendency, open field behaviour at two different ages, foraging/exploration, response to a simulated aerial predator attack and tonic immobility. All the tests are thoroughly described in Agnvall et al. (2012).

The results revealed that most of the behaviours measured in this study did not differ between the two selected strains. In the parental generation, a few behaviours differed between the divided strains such as distance moved in social reinstatement, time spent in periphery in the open field test as chicks and stand alert in the aerial predator test. There was also a significant sex $\mathrm{x}$ selection interaction in the explorative behaviour during the aerial predator test. In the fifth selected generation, there were no significant effects of selection on tonic immobility and foraging/exploration while time spent in the social zone in the social reinstatement test differed between the strains. Both variables measured in the open field test had a significant interaction between sex and selection. Overall, the differences in behaviours are few between the strains and, although the fear of human trait, the behaviour the animals were selected upon, differed significantly, the selection seems to have a relatively small impact on other aspects of fearfulness as well as sociality, exploration and foraging behaviour. In conclusion, since the selection on reduced fear of humans has caused significant effects on several phenotypic traits associated with the domesticated phenotype (Agnvall et al. 2014; Agnvall et al. 2012; Agnvall et al. 2015), this indicated that fundamental behaviour is more resilient against the selection. 


\section{Discussion}

The aim of this thesis was to investigate the correlated selection responses due to divergent selection on the fear of human response in the Red Junglefowl. In paper I, we concluded that the fear of human trait had a low but significant genetic heritability component, hence it was possible to select on this trait. The selection trait showed a genetic correlation with traits connected to the domesticated phenotype such as propensity to search for hidden food and exploration (paper I). In further generations, the selection affected several traits connected to the domesticated phenotype such as size, social behaviour, feeding motivation, metabolism and brain size (paper II, III, IV). On the other hand, after five selected generations, the behaviour measured between the strains seemed to be rather unaffected by the selection. There were few behavioural differences between Po and S5, which indicates that fundamental species-specific behaviour is more resilient to correlated selection responses than phenotypes related to growth and reproduction (paper V). The modification of the animals that has appeared due to the selection generally goes in the direction of the domesticated phenotype, which indicates that tameness may be a necessary first step in the domestication process of the chicken.

\section{The domestic phenotype}

\section{Behaviour effects}

Generally, the behaviour repertoire of a domesticated animal remains unchanged compared to the wild ancestor, but the stimulus threshold at which behaviour is expressed is altered. In paper $\mathrm{V}$, we investigated the behaviour modifications due to the selection on tameness with the main focus on different aspects of fearfulness, social behaviour and exploration in a foraging environment. Although there were few differences between Po and S5, the selection seems to have affected some behaviour responses. Within $\mathrm{S}_{5}$, there was a main effect of selection in the aerial predator test and an interaction between selection and sex in the social reinstatement and open field test, meaning that the selection has affected the sexes differently. Fear of humans in our selection strain, or in chickens in general, seems to be a very special and isolated trait that does not affect the overall fearfulness of the chicken.

The fear tests used in this study are frequently used in chicken research and are considered to assess fear (Campler et al. 2009; Håkansson and Jensen 2005, 2008; Jöngren et al. 2010). In an earlier study, Jöngren et al. (2010) exposed Red Junglefowl females to similar fear tests and found two major components explaining $48.4 \%$ of the variance in a PCA. The first component was interpreted as a general fear factor whereas the second was mainly explained by TI. This indicates a low correlation between general fear and TI. Interestingly, there are other studies pointing in the same direction (Mignon-Grasteau et al. 2003; Schütz et al. 2004) i.e., that TI is differentiated from general fear. TI is probably a defense reaction to a predator attack and perhaps our 
selection trait, fear of humans as predators, would come out as different from general fear as well.

When an animal experiences fear, activation of the HPA-axis occurs simultaneously with a behaviour response (Labar and Ledoux 2010). The HPA-axis has previously been investigated in a comparative study between the domesticated chicken and the Red Junglefowl which revealed a stronger physiological reaction but a faster recovery in the wild type (Ericsson et al. 2014). Since the selection in this thesis is based on a fear behaviour, the alterations in corticosterone produced by the HPA-axis were of great interest to us. Indeed, modification of the adrenals was also one of the differences that occurred in the silver foxes selected on a similar trait. The foxes selected on tameness had less active adrenals than the wild type starting from the $10^{\text {th }}$ selected generation (Trut et al. 1972). In our study, however, there was no effect of selection on corticosterone level, but we could see a time effect showing that the animals did experience fear during the restraint stress test (paper III). Of course, it is difficult to know if the corticosterone levels would change after additional generations, perhaps six generations in birds are too few to alter the HPA-axis. According to Trut et al. (2013), some of the parental foxes in the project were selected from various farms based on their lack of a distinct aggressive response to humans. It is, therefore, possible that the parental animals in the fox experiment already had less active HPA-axis from the beginning. In comparison, the differences in adrenals in the wild caught rats selected on low aggression towards humans, did not appear until after 20 generations (Naumenko et al. 1989). In this present project, we started our selection by dividing a mixed population into three categories solely depending on their fear score from the standardized test.

\section{Weight}

The main change in appearance found in this experiment was a reduced size in high fear compared to low fear birds. The animals selected on low fear of humans had a significantly larger body weight at any age measured (paper I, II, III, IV). This is not in accordance with the generally observed effect in the domesticated phenotype where early domesticated animals usually reduce their sizes (Tchernov and Horwitz 1991). The metabolic rate, as well as the feed efficiency, was also higher in birds selected on low fear of humans. These findings are probably all connected in that birds with higher metabolic rate fed more and gained more weight in relation to feed intake because of the feed efficiency. A mediating factor of the metabolism alterations, at least in the low fear males, may be the increased secretion of 5-HT in blood measured in S6 (paper III). Even though the connection between platelet 5 - HT and central 5 -HT is not fully understood, the higher levels in the low fear males are interesting since central 5-HT is known to have effects on feeding and satiety (Voigt and Fink 2015), and 5-HT in blood platelets originates from the gastrointestinal tract (Mück-Šeler and Pivac 2011). In addition to its important role in feeding and satiety, 5-HT plays an important role in fear (Bolhuis et al. 2009). Animals with higher levels of 5-HT experience less fear 
and are able to allocate their resources into growth and reproduction rather than vigilance.

The weight difference was also one of the first modifications that appeared in this selection. The $\mathrm{L}$ animals were generally larger and produced larger eggs and offspring (paper II). In S5, this was further investigated with the calculation of feed efficiency that revealed an interaction between sex and selection indicating that low fear females gained more weight in relation to feed intake (paper III). The weights of eggs and offspring, as well as growth, are related to alterations in reproduction which were also seen in the experiment where silver foxes were selected for low fear of humans (Trut et al. 2009). The foxes selected on low fear of humans altered their reproduction into two seasons per year compared to the wild type that only reproduces once a year (Belyaev and Borodin 1982).

When investigating the gene expression differences between the two strains, Bélteky et al. (2016) found two differentially expressed genes located centrally in a QTL region called GROWTH1 on chromosome 1 that previously has been associated with a large size difference between a layer breed and the Red Junglefowl (Kerje et al. 2003a). Interestingly, this QTL region has also been associated with differences in social behaviour between domesticated chickens and Red Junglefowl. During chicken domestication, social behaviour as well as size of the animals has been altered, as mentioned before. Generally, the domesticated chicken has a higher social tolerance and, regarding chickens bred for the egg and meat industry, they are generally larger than the wild type. The differences seen in this project point in the same direction with larger animals with low fear of humans expressing more aggressive behaviour than the high fear animals.

\section{Colouration}

The colouration was also one of the first differences seen in the farm fox project resulting after only a few generations (Belyaev et al. 1985). This has not yet been measured systematically in this project although no white pigmentations have been observed. Domesticated chickens are present in many different colours and previous research has shown that chickens that are homozygous for the dominant white allele, PMEL17, hence the white domesticated variant, were both less aggressive and less explorative than the chickens homozygous for the wild type allele (Karlsson et al. 2010; Karlsson et al. 2011). This indicates that the colouration in the domesticated chicken, just as in the foxes bred on tameness, is somehow related to the behaviour that corresponds to the domesticated phenotype. However, since Red Junglefowl, unlike the silver fox, do not have white colourations in the wild type, a change in colouration would probably have to occur through a spontaneous mutation, although possible epigenetic effects on pigmentation should not be excluded. 


\section{Brain and other organs}

In paper IV, we revealed that the brain and organ weight had been modified due to the selection on tameness. A reduction of brain weight and size is known as a domestic feature and this may be an adaptation to a new niche since domesticated animals are provided with food and shelter by humans. The domesticated chicken has a smaller brain relative to body weight than the Red Junglefowl (Jackson and Diamond 1996) although the absolute weight is larger in the White leghorn due to the large weight difference (Henriksen et al. 2016). Even among domesticated chickens there are alterations in the brain morphology between breeds (Rehkämper et al. 2003). The brain size differences in our selected birds are a result of a correlated response to the active selection on tameness. Guppies actively selected on brain size responded quickly to the selection and in the second selected generation the differences in brain size were already prominent (Kotrschal et al. 2013). Number of offspring and gut size seemed to have a negative correlation with a large brain in guppies, which strengthens the theory of a trade-off between a large brain and other energy expensive organs such as gonads, fat storage, and muscle tissue (Isler and van Schaik 2006a). In our chickens selected on tameness, the high fear animals had heavier brains than the low fear animals. Interestingly, their testicles, as well as all other harvested organs, were larger in relation to body weight. However, since the body weight significantly differed between the strains, the absolute values did not differ; the high fear animals seem to have organs of about the same weight as the low fear animals that have a significantly larger body weight. Could it be that the high fear animals invest more in their organs and less in their total body mass and fat storage? It would be interesting to investigate this further by measuring sperm number and fat storage.

In the guppies, large brained females outperformed those with small brains in a learning assay indicating that brain size correlates with cognitive ability (Kotrschal et al. 2013). The cognitive ability in the chickens as a consequence of small or large brain size would be interesting to further investigate with the high vs low fear animals. Although the chicken breed with the relatively largest brain, the White Crested Polish Chicken, does not show improved cognitive ability in behaviour tests (Mehlhorn and Rehkämper 2013), we know from previous work that Red Junglefowl differ from the White Leghorn in their cognitive ability (Lindqvist and Jensen 2009).

\section{Implications of this project}

\section{Chicken domestication}

Originally, chickens were probably not domesticated because of our interest in their eggs or meat. Recent data has shown that the evolutionary roots of the chicken are related to the distribution of cockfighting which was probably of the greatest interest when humans started to keep chickens (Liu et al. 2006). It is, therefore, likely that intra-aggressive males were of great interest when breeding in order to produce 
successful cockfighting birds. The relation between fear of humans and aggressive males is interesting since animals that possess pure aggressive behaviour without underlying fear ought to have a low fear of humans. On the other hand, the relations an animal has to humans and to conspecifics are different traits, but low fear of humans could indicate an overall more confident animal. The results from paper II, indicate that the animals with low fear of humans were more dominant and expressed more aggressive behaviour towards the animals from the high fear strain when tested with a limited resource.

It is interesting that the main alterations of the animals selected on low fear of humans are similar to traits favourable in chicken production such as larger eggs, larger body weight and more efficient growth. These are traits that have been intensely and actively selected upon during the last 50 years (Zuidhof et al. 2014) in order to increase the meat and egg yield. The changes we see in our selected chickens are, of course, not as prominent as in the production industry, but, if we are allowed to speculate, these alterations were perhaps seen in an early stage in the process of the chicken domestication. The Greylag goose was probably the first domesticated bird (Sossinka 1982), but has never reached the high popularity of the chicken. If growth and egg weight were one of the earliest modifications in domestication, this could be one key factor in the popularity of the chicken.

\section{Unpredictability of genetic correlation}

In paper I, we found a genetic correlation between the trait selected upon and other behavioural responses associated with exploration and fear. The genetic correlations were observed in the propensity to search for hidden food and changes between food containers in the foraging and exploration test as well as exploration in the aerial predator test. Due to the genetic correlation, we expected these traits to follow the divergence of the selection trait; however, when the tests were repeated in $\mathrm{S}_{5}$, this was not found and there were no significant differences between the selection strains in these variables. In a simulation experiment, Gromko (1995) concluded that there are many possible combinations of pleiotropic effects characterized by the same value for genetic correlation, which means that the genetic correlation does not uniquely determine a particular set of pleiotropic effects. So, if the genetic correlations calculated in our study were due to pleiotropic effects, this could have had a substantial impact on the variation in the correlated response of the behaviour in the chickens. However, as reported before in this thesis, behaviour seems to be rather resilient to this selection and few behaviour traits seem to be correlated to the selection

\section{Method discussion}

\section{The selection test}

The core of the project is the selection and, therefore, the fear of human test, which was designed before Po was hatched. For selecting on fear of humans, I think it is valuable 
that, in our selection test, the whole body of the test person is located in the arena together with the chicken. In other fear of human tests, only the hand has been visible to the animal (Albert et al. 2008; Belyaev 1979; Hansen 1996), but, since chickens are imprinted as newly hatched, it is possible that the animals already have been imprinted on the test persons' hands during the first hours in life. This makes it crucial for a selection test to encompass the whole body of the test person.

\section{Breeding and sample size}

This project started out with a mix of two populations in order to maximize the genetic variation in the animals. A weakness of the project is the sample size in each of the selection lines. Due to the resource limitations, it was impossible to have several replicated populations which of course would have been favorable. Due to the small sample size, the breeding selection has varied between $75 \%$ to $13 \%$ of the birds in each generation within selection strain. The selection has always been conducted with a wide family representation as highest priority and fear score as the second priority, and brothers and sisters have not been paired. It is impossible to exclude the impact of genetic drift on the selection, but, since the selection has only been ongoing for six generations, the genes affecting the results are probably not fixated or eliminated. Although we cannot exclude the impact of genetic drift, many of the variables in the project are diverging in the same direction as the selection trait with the unselected line remaining similar to Po. When studying the differences in gene expression in the hypothalamus of the selected chickens, Bélteky et al. (2016) found no differentially expressed genes in the Po. This indicates that we probably did not unintentionally breed on animals with a diverged gene expression from the beginning.

\section{Fear of humans vs imprinting in chickens}

The fear of human trait has previously been proven to be important for the domestication process in mammalian animals, as mentioned for the silver fox, mink and rats. The question is, how important is this trait for a species that shows filial imprinting as newly hatched? During the first hours of life, chickens are imprinted on any large, moving object in their vicinity. Wild Red Junglefowl chicks could easily have been imprinted on humans and they would then have a low fear of humans by default. This would, of course, not be inherited, but the process could be repeated in every generation. Imprinting has, in fact, been altered during domestication (Kirkden et al. 2008). So, was the reduced fear of humans really a crucial trait for the domestication of the chicken? According to the results from this project, it seems that, when selecting on this trait, the correlated selection responses are in the direction of the domesticated phenotype of the chicken. This could indicate that the trait was important in the domestication process of the chicken. 


\section{Conclusions}

In conclusion, selection on divergent fear of human in Red Junglefowl alters a number of phenotypic traits. The animals selected on low fear of human are, after six selected generations, more dominant, larger, produce larger eggs and offspring, and also have increased blood 5-HT, higher metabolism, higher feed efficiency and lower brain weight. The selection has affected only a few behaviour responses of which some are sex dependent. These modifications in the animals are probably correlated selection responses due to the selection criteria, the fear of human response. These results correspond to some extent with previous selection experiments on tameness in mammals such as the silver fox, mink and rat. Furthermore, this indicates the importance of tameness in the process of domestication. 


\section{Acknowledgement}

First and foremost, I would like to thank my super supervisor, Per Jensen. It has been an honor to be one of your PhDstudents (and, thanks to my kids, I have had this honor for quite some time-()). Thanks for always having time for me when popping by your office all the time, and for never laughing at my sometimes naïve and too basic questions. Thanks for opening my eyes and widening my mind to think more broadly when I have been too focused on details. I will always remember the truly happy face you expressed when I said that Johanna and I were expecting our first kid. When I told you about the second, I will remember the face, "Will she never finish?:- As Mia wrote in her thesis, if I could go back in time and redo the PhD, I would have chosen you as my supervisor all over again.

To the best technicians ever, Lejla, Petros and Ann-Charlotte. The AVIAN-group is lucky to have you!

Huge thanks for input and nice discussions in the AVIAN group during the years!

Many thanks to "my" excellent master students, Anser, Sara and Rebecca. Paper II and III are thanks to you guys!

Chickens! Of course I have to thank all of "my" chickens (and I have quite a few on my conscience). Forgive me for all the scary test situations I have put all of you through and for your bitter end in the name of science. Without all of you we would still wonder about so many things regarding domestication and fearfulness.

Huge thanks to Emily and Ann-Sofie, for proofreading the thesis with your perfect-Englishglasses :)

To all my amazing colleagues, past and present. Jag har verkligen älskat att jobba på biologi och jag önskar jag kunde vara kvar längre.

Tänk att få sitta i VIP-rummet på LiU! Tusen tack till David och Skalman för all möjlig hjälp med dator (och mobil)bekymmer jag haft genom åren!

Jag har haft förmånen att sitta i det bästa kontoret av dom alla! Anna-Carin, Mia, AnnSofie och Lina (nästan samma kontor). Tänk vilken lycka att få dela kontor med kollegor som blir vänner. Att få dela en så stor del av livet med människor som man verkligen tycker om, vi ses ju trots allt fler timmar på dygnet än vad jag träffar min familj. Jag har alltid älskat jobbet och kontoret har varit en stor del av detta. Att få en puff i rätt riktning när man känner sig kass och vilsen, att få råd när man inte vet hur man ska göra och att få skratta när man verkligen behöver det. Ett extra stort tack till Ann-Sofie som har fått stå ut med min självcentrering under denna sista tid, alla tankar jag tänkt högt på kontoret och alla råd jag frågat om. Den här avhandlingen skulle ha kunnat tillägnas dig.

Pia, Karin, Mia, Anna-Carin, Ann-Sofie och Josefina! Tack för all pepp och lugnande ord under middagarna, verkligen en höjdpunkt i månaden!

Markus, tack för allt kul vi hade under våra år tillsammans med projektet! Jag har saknat dig mycket under åren! 
Johan! Partners in crime, snacka om skönt att få göra resan tillsammans! Tack för allt pepp, alla morgonsnack, alla råd och att jag fått tänka högt :) Snacka om att vi kommer att rocka (:)

Tack Mamma för att jag fick utveckla mitt djurintresse (även om jag oftast gjorde det utan tillåtelse) och Pappa för att du la in ditt veto i fråga om gymnasieval. Jag skulle även vilja tacka min biologilärare på högstadiet, Eva Johansson, den bästa läraren jag haft och som öppnade upp en helt ny värld för mig, en värld som jag ville vara en del av.

Världens bästa svärföräldrar, Kristina och Kenneth! Jag är så glad att jag har fătt bli en del av er familj, en familj med så mycket värme och glädje som alltid ställer upp och som alltid är där! Och tack för lånet av Landet och de fina figurerna till avhandlingen :-)

Michael och Åsa! Vad vore livet i Norsholm utan er! Tack för alla drinkkvällar vi haft och för alla vi kommer att ha (:) Att få gå in och umgås med er i torktumlaren som det lätt blir med fyra trötta barn, fyra pratsjuka vuxna och tre understimulerade hundar, det sätter en extra krydda på livet!

Johanna Rudenstam och Åsa! Vänner och familj för livet, vänner på agilityplan, vänner i vått och torrt! Älskar er $<3$

Alltså, jag måste nog även tacka mina hundar, alla mina hundar som jag har och har haft. Att få umgås och träna med er, mina vänner, är obetalbar. Att få känna samspelet med er och att leka agility, det är nog nästan det bästa jag vet. Milo, Soda, Heba, Lo, Tia, och Daga ni är med mig för evigt.

Kusinerna, vet faktiskt inte vem jag skulle vara utan er. Vilken tur jag har som fătt just er till mina <3 Detta är antagligen den enda bok jag kommer att skriva så jag passar på att tacka er för alla upptåg vi gjort och alla upplevelser vi delar! Carro, min bästa person som alltid bara är där för mig, alltid! Tänk allt galet roligt vi gjort under alla år, och tänk så himla mycket mer roligt vi har kvar! Bästa systern Ann-Charlotte som gör mitt liv så mycket mer roligt som med en storasysters stränghet ser till att jag blir lite bättre och Marcus, trots att du snart är 50, så är du den bästa brorsan jag vet.

Och till sist, den bästa personen av dom alla, min fru, min Johanna! Jag älskar dig mer vad du kan föreställa dig och du är min person. Du gör mitt liv så mycket roligare, så mycket finare och så mycket mer, av allt! Du vet när jag behöver muntras upp, du får mig att skratta, du vet när det är dags att skicka iväg mig på agilityträning och du vet när något inte är bra. Du ställer alltid upp i vått och torrt och jag är stolt över att just jag fick äran att bli din fru. Att få dela livet med dig, att få skratta med dig, att bråka med dig och att få gråta med dig, det är det som gör livet och vi rockar på att dela det tillsammans! Du är min person, för alltid 


\section{References}

Abeyesinghe, S. M., McLeman, M. A., Owen, R. C., McMahon, C. E. \& Wathes, C. M. 2009. Investigating social discrimination of group members by laying hens. Behavioural Processes, 81, 1-13.

Agnvall, B., Ali, A., Olby, S. \& Jensen, P. 2014. Red Junglefowl (Gallus gallus) selected for low fear of humans are larger, more dominant and produce larger offspring. animal, 8, 1498-1505.

Agnvall, B., Jöngren, M., Strandberg, E. \& Jensen, P. 2012. Heritability and Genetic Correlations of Fear-Related Behaviour in Red Junglefowl-Possible Implications for Early Domestication. PLOS ONE, 7, e35162.

Agnvall, B., Katajamaa, R., Altimiras, J. \& Jensen, P. 2015. Is domestication driven by reduced fear of humans? Boldness, metabolism and serotonin levels in divergently selected red junglefowl (Gallus gallus). Biology Letters, 11.

Al-Nasser, A., Al-Khalaifa, H., Al-Saffar, A., Khalil, F., Albahouh, M., Ragheb, G., Al-Haddad, A. \& Mashaly, M. 2007. Overview of chicken taxonomy and domestication. World's Poultry Science Journal, 63, 285-300.

Albert, F. W., Carlborg, Ö., Plyusnina, I., Besnier, F., Hedwig, D., Lautenschläger, S., Lorenz, D., McIntosh, J., Neumann, C., Richter, H., Zeising, C., Kozhemyakina, R., Shchepina, O., Kratzsch, J., Trut, L., Teupser, D., Thiery, J., Schöneberg, T., Andersson, L. \& Pääbo, S. 2009. Genetic Architecture of Tameness in a Rat Model of Animal Domestication. Genetics, 182, 541-554.

Albert, F. W., Shchepina, O., Winter, C., Römpler, H., Teupser, D., Palme, R., Ceglarek, U., Kratzsch, J., Sohr, R., Trut, L. N., Thiery, J., Morgenstern, R., Plyusnina, I. Z., Schöneberg, T. \& Pääbo, S. 2008. Phenotypic differences in behavior, physiology and neurochemistry between rats selected for tameness and for defensive aggression towards humans. Hormones and Behavior, 53, 413-421.

Andersson, M., Nordin, E. \& Jensen, P. 2001. Domestication effects on foraging strategies in fowl. Applied Animal Behaviour Science, 72, 51-62.

Appleby, M. C., Mench, J. A. \& Hughes, B. O. 2004. Poultry behaviour and welfare. Cambridge: CABI Publishing.

Archer, J. 1973. Tests for emotionality in rats and mice: A review. Animal Behaviour, 21, 205235 .

Bélteky, J., Agnvall, B., Johnsson, M., Wright, D. \& Jensen, P. 2016. Domestication and tameness: brain gene expression in red junglefowl selected for less fear of humans suggests effects on reproduction and immunology. Royal Society Open Science, 3.

Belyaev, D. K. 1979. Destabilizing selection as a factor in domestication. Journal of Heredity, 70, 301-308.

Belyaev, D. K. \& Borodin, P. M. 1982. The Influence of Stress on Variation and Its Role in Evolution. Biologisches Zentralblatt, 100, 705-714. 
Belyaev, D. K., Plyusnina, I. Z. \& Trut, L. N. 1985. Domestication in the silver fox (Vulpes fulvus Desm): Changes in physiological boundaries of the sensitive period of primary socialization. Applied Animal Behaviour Science, 13, 359-370.

Blanchard, R. J., Flannelly, K. J. \& Blanchard, D. C. 1986. Defensive behaviors of laboratory and wild $<\mathrm{em}>$ Rattus norvegicus. $</ \mathrm{em}>$. Journal of Comparative Psychology, 100, 101-107.

Boice, R. 1973. Domestication. Psychological Bulletin, 80, 215-230.

Boissy, A. 1995. Fear and Fearfulness in Animals. The Quarterly Review of Biology, 70, 165191.

Bolhuis, J. E., Ellen, E. D., Van Reenen, C. G., De Groot, J., Napel, J. T., Koopmanschap, R. E., De Vries Reilingh, G., Uitdehaag, K. A., Kemp, B. \& Rodenburg, T. B. 2009. Effects of genetic group selection against mortality on behavior and peripheral serotonin in domestic laying hens with trimmed and intact beaks. Physiology and Behavior, 97, 470-475.

Borowicz, V. A. \& Graves, H. B. 1986. Social preferences of domestic hens for domestic vs. red junglefowl males and females. Behavioural Processes, 12, 125-134.

Campler, M., Jöngren, M. \& Jensen, P. 2009. Fearfulness in red junglefowl and domesticated White Leghorn chickens. Behavioural Processes, 81, 39-43.

Campo, J., Gil, M., Torres, O. \& Davila, S. 2001. Association between plumage condition and fear and stress levels in five breeds of chickens. Poultry Science, 80, 549-552.

Chase, I. D. 1982. Behavioral Sequences during Dominance Hierarchy Formation in Chickens. Science, 216, 439-440.

Clarke, C. H. \& Jones, R. B. 2001. Domestic chicks' runway responses to video images of conspecifics. Applied Animal Behaviour Science, 70, 285-295.

Clutton-Brock, J. 1981. Domesticated animals from early times. Domesticated animals from early times.

Clutton-Brock, J. 1999. A Natural History of Domesticated Mammals. Cambridge: Cambridge University Press.

Collias, N. E. \& Collias, E. C. 1967. A Field Study of the Red Jungle Fowl in North-Central India. The Condor, 69, 360-386.

Collias, N. E. \& Collias, E. C. 1996. Social organization of a red junglefowl,Gallus gallus, population related to evolution theory. Animal Behaviour, 51, 1337-1354.

D'Eath, R. B. \& Dawkins, M. S. 1996. Laying hens do not discriminate between video images of conspecifics. Animal Behaviour, 52, 903-912.

D'Eath, R. B. \& Stone, R. J. 1999. Chickens use visual cues in social discrimination: an experiment with coloured lighting. Applied Animal Behaviour Science, 62, 233-242. 
Dawkins, M. S. 1995. How Do Hens View Other Hens? The Use of Lateral and Binocular Visual Fields in Social Recognition. Behaviour, 132, 591-606.

de Haas, E. N., Kemp, B., Bolhuis, J. E., Groothuis, T. \& Rodenburg, T. B. 2013. Fear, stress, and feather pecking in commercial white and brown laying hen parent-stock flocks and their relationships with production parameters. Poultry Science, 92, 2259-2269.

Devlin, R. H., Biagi, C. A., Yesaki, T. Y., Smailus, D. E. \& Byatt, J. C. 2001. Growth of domesticated transgenic fish. Nature, 409, 781-782.

Diamond, J. 2002. Evolution, consequences and future of plant and animal domestication. Nature, 418, 700-707.

Ducos, P. 1989. The walking larder: Patterns of domestication, pastoralism and predation. London: Unwin Hyman.

Dwyer, C. M. 2004. How has the risk of predation shaped the behavioural responses of sheep to fear and distress? Animal Welfare, 13, 269-281.

Ebinger, P. 1974. A cytoarchitectonic volumetric comparison of brains in wild and domestic sheep. Zeitschrift fuer Anatomie und Entwicklungsgeschichte, 144, 267-302.

Ebinger, P. 1995. Domestication and Plasticity of Brain Organization in Mallards (Anas platyrhynchos). Brain, Behavior and Evolution, 45, 286-300.

Ebinger, P. \& Röhrs, M. 1994. Volumetric analysis of brain structures, especially of the visual system in wild and domestic turkeys (Meleagris gallopavo). Journal fur Hirnforschung, 36, 219-228.

Eklund, B. \& Jensen, P. 2010. Domestication effects on behavioural synchronization and individual distances in chickens (Gallus gallus). Behavioural Processes, 86, 250-256.

Emmerson, D. 1997. Commercial approaches to genetic selection for growth and feed conversion in domestic poultry. Poultry Science, 76, 1121-1125.

Ericsson, M., Fallahsharoudi, A., Bergquist, J., Kushnir, M. M. \& Jensen, P. 2014. Domestication effects on behavioural and hormonal responses to acute stress in chickens. Physiology \& Behavior, 133, 161-169.

Eriksson, J., Larson, G., Gunnarsson, U., Bed'hom, B., Tixier-Boichard, M., Strömstedt, L., Wright, D., Jungerius, A., Vereijken, A., Randi, E., Jensen, P. \& Andersson, L. 2008. Identification of the <italic $>$ Yellow Skin $</$ italic $>$ Gene Reveals a Hybrid Origin of the Domestic Chicken. PLoS Genet, 4, e1000010.

Forkman, B., Boissy, A., Meunier-Salã̃¹/4n, M. C., Canali, E. \& Jones, R. B. 2007. A critical review of fear tests used on cattle, pigs, sheep, poultry and horses. Physiology \&amp; Behavior, 92, 340-374.

Frantz, L. A. F., Mullin, V. E., Pionnier-Capitan, M., Lebrasseur, O., Ollivier, M., Perri, A., Linderholm, A., Mattiangeli, V., Teasdale, M. D., Dimopoulos, E. A., Tresset, A., Duffraisse, M., McCormick, F., Bartosiewicz, L., Gál, E., Nyerges, É. A., Sablin, M. V., Bréhard, S., Mashkour, M., Bălăşescu, A., Gillet, B., Hughes, S., Chassaing, O., Hitte, C., Vigne, J.-D., Dobney, K., Hänni, C., Bradley, D. G. \& 
Larson, G. 2016. Genomic and archaeological evidence suggest a dual origin of domestic dogs. Science, 352, 1228-1231.

Gallup, G. G. 1979. Tonic immobility as a measure of fear in domestic fowl. Animal Behaviour, 27, 316-317.

Gibbons, J., Lawrence, A. \& Haskell, M. 2009. Responsiveness of dairy cows to human approach and novel stimuli. Applied Animal Behaviour Science, 116, 163-173.

Gromko, M. H. 1995. Unpredictability of correlated response to selection: pleiotropy and sampling interact. Evolution, 685-693.

Gutierrez-Gil, B., Ball, N., Burton, D., Haskell, M., Williams, J. L. \& Wiener, P. 2008. Identification of Quantitative Trait Loci Affecting Cattle Temperament. Journal of Heredity, 99, 629-638.

Hansen, S. W. 1996. Selection for behavioural traits in farm mink. Applied Animal Behaviour Science, 49, 137-148.

Hargreaves, A. L. \& Hutson, G. D. 1990. The effect of gentling on heart rate, flight distance and aversion of sheep to a handling procedure. Applied Animal Behaviour Science, 26, 243252.

Hazard, D., Moreno, C., Foulquie, D., Delval, E., Francois, D., Bouix, J., Salle, G. \& Boissy, A. 2014. Identification of QTLs for behavioral reactivity to social separation and humans in sheep using the OvineSNP5o BeadChip. Bmc Genomics, 15.

Henriksen, R., Johnsson, M., Andersson, L., Jensen, P. \& Wright, D. 2016. The domesticated brain: genetics of brain mass and brain structure in an avian species. Scientific Reports, 6, 34031.

Håkansson, J. \& Jensen, P. 2005. Behavioural and morphological variation between captive populations of red junglefowl (Gallus gallus) - possible implications for conservation. Biological Conservation, 122, 431-439.

Håkansson, J. \& Jensen, P. 2008. A longitudinal study of antipredator behaviour in four successive generations of two populations of captive red junglefowl. Applied Animal Behaviour Science, 114, 409-418.

Isler, K. \& van Schaik, C. 2006a. Costs of encephalization: the energy trade-off hypothesis tested on birds. Journal of Human Evolution, 51, 228-243.

Isler, K. \& van Schaik, C. P. 2006b. Metabolic costs of brain size evolution. Biology Letters, 2, 557-560.

Jackson, S. \& Diamond, J. 1996. Metabolic and Digestive Responses to Artificial Selection in Chickens. Evolution, 50, 1638-1650.

Jensen, P. \& Wright, D. 2014. Behavioral genetics and animal domestication. Genetics and the Behavior of Domestic Animals, 2nd edn. Academic Press (Elsevier), San Diego, California, 41-80. 
Jöngren, M., Westander, J., Nätt, D. \& Jensen, P. 2010. Brain gene expression in relation to fearfulness in female red junglefowl (Gallus gallus). Genes, Brain and Behavior, 9, 751-758.

Karlsson, A.-C., Kerje, S., Andersson, L. \& Jensen, P. 2010. Genotype at the PMEL17 locus affects social and explorative behaviour in chickens. British Poultry Science, 51, 170-177.

Karlsson, A.-C., Mormede, P., Kerje, S. \& Jensen, P. 2011. Genotype on the Pigmentation Regulating PMEL17 Gene Affects Behavior in Chickens Raised Without Physical Contact with Conspecifics. Behavior Genetics, 41, 312-322.

Kerje, S., Carlborg, Ö., Jacobsson, L., Schütz, K., Hartmann, C., Jensen, P. \& Andersson, L. 2003a. The twofold difference in adult size between the red junglefowl and White Leghorn chickens is largely explained by a limited number of QTLs. Animal Genetics, 34, 264-274.

Kerje, S., Lind, J., Schütz, K., Jensen, P. \& Andersson, L. 2003b. Melanocortin 1receptor $(\mathrm{MC} 1 \mathrm{R})$ mutations are associated with plumage colour in chicken. Animal Genetics, $34,241-248$.

Kirkden, R. D., Lindqvist, C. \& Jensen, P. 2008. Effects of domestication on filial motivation and imprinting in chicks: comparison of red junglefowl and White Leghorns. Animal Behaviour, 76, 287-295.

Kotrschal, A., Rogell, B., Bundsen, A., Svensson, B., Zajitschek, S., Brännström, I., Immler, S., Maklakov, Alexei A. \& Kolm, N. 2013. Artificial Selection on Relative Brain Size in the Guppy Reveals Costs and Benefits of Evolving a Larger Brain. Current Biology, 23, 168-171.

Kruska, D. 1988a. Effects of domestication on brain structure and behavior in mammals. Human Evolution, 3, 473 - 485.

Kruska, D. 1988b. Mammalian Domestication and its Effect on Brain Structure and Behavior. In: Intelligence and Evolutionary Biology (Ed. by Jerison, H. J. \& Jerison, I.), pp. 211-250. Berlin, Heidelberg: Springer Berlin Heidelberg.

Kruska, D. 1996. The effect of domestication on brain size and composition in the mink (Mustela vison). Journal of Zoology, 239, 645-661.

Kukekova, A. V., Trut, L. N., Chase, K., Kharlamova, A. V., Johnson, J. L., Temnykh, S. V., Oskina, I. N., Gulevich, R. G., Vladimirova, A. V., Klebanov, S., Shepeleva, D. V., Shikhevich, S. G., Acland, G. M. \& Lark, K. G. 2011. Mapping Loci for Fox Domestication: Deconstruction/Reconstruction of a Behavioral Phenotype. Behavior Genetics, 41, 593-606.

Kukekova, A. V., Trut, L. N., Chase, K., Shepeleva, D. V., Vladimirova, A. V., Kharlamova , A. V., Oskina, I. N., Stepika, A., Klebanov, S., Erb, H. N. \& Acland, G. M. 2008. Measurement of Segregating Behaviors in Experimental Silver Fox Pedigrees. Behavior Genetics, 38, 185-194.

Künzl, C., Kaiser, S., Meier, E. \& Sachser, N. 2003. Is a wild mammal kept and reared in captivity still a wild animal? Hormones and Behavior, 43, 187-196. 
Labar, K. S. \& Ledoux, J. E. 2010. Coping with Danger: The Neural Basis of Defensive Behavior and Fearful Feelings. In: Comprehensive Physiology: John Wiley \& Sons, Inc.

Lindqvist, C. \& Jensen, P. 2009. Domestication and stress effects on contrafreeloading and spatial learning performance in red jungle fowl (Gallus gallus) and White Leghorn layers. Behavioural Processes, 81, 80-84.

Lindqvist, C. E. S., Sch Ã1/4tz, K. E. \& Jensen, P. 2002. Red Jungle Fowl Have More Contrafreeloading than White Leghorn Layers: Effect of Food Deprivation and Consequences for Information Gain. Behaviour, 139, 1195-1209.

Liu, Y.-P., Wu, G.-S., Yao, Y.-G., Miao, Y.-W., Luikart, G., Baig, M., Beja-Pereira, A., Ding, Z.-L., Palanichamy, M. G. \& Zhang, Y.-P. 2006. Multiple maternal origins of chickens: Out of the Asian jungles. Molecular Phylogenetics and Evolution, 38, 12-19.

Malmkvist, J. \& Hansen, S. W. 2002. Generalization of fear in farm mink, Mustela vison, genetically selected for behaviour towards humans. Animal Behaviour, 64, 487-501.

Meadows, J. R. S. 2014. Sheep: Domestication. In: Encyclopedia of Global Archaeology (Ed. by Smith, C.), pp. 6597-660o. New York, NY: Springer New York.

Mehlhorn, J. \& Rehkämper, G. 2013. Some Remarks on Bird's Brain and Behavior under the Constraints of Domestication. ISRN Evolutionary Biology, 2013.

Mignon-Grasteau, S., Roussot, O., Delaby, C., Faure, J. M., Mills, A., Leterrier, C., Guéméné, D., Constantin, P., Mills, M., Lepape, G. \& Beaumont, C. 2003. Factorial correspondence analysis of fear-related behaviour traits in Japanese quail. Behavioural Processes, 61, 69-75.

Mück-Šeler, D. \& Pivac, N. 2011. Serotonin. Periodicum biologorum, 113, 29-41.

Naumenko, E. V., Popova, N. K., Nikulina, E. M., Dygalo, N. N., Shishkina, G. T., Borodin, P. M. \& Markel, A. L. 1989. Behavior, adrenocortical activity, and brain monoamines in Norway rats selected for reduced aggressiveness towards man. Pharmacology Biochemistry and Behavior, 33, 85-91.

Nicol, C. J. 2015. The Behavioural Biology of Chickens: CABI.

Oltenacu, P. A. \& Broom, D. M. 2010. The impact of genetic selection for increased milk yield on the welfare of dairy cows. Animal Welfare, 19, 39-49.

Plogmann, D. \& Kruska, D. 1990. Volumetric comparison of auditory structures in the brains of European wild boars (Sus scrofa) and domestic pigs (Sus scrofa f. dom.). Brain, Behavior and Evolution, 35, 146-155.

Popova, N. K., Voitenko, N. N., Kulikov, A. V. \& Avgustinovich, D. F. 1991. Evidence for the involvement of central serotonin in mechanism of domestication of silver foxes. Pharmacology Biochemistry and Behavior, 40, 751-756.

Price, E. O. 1999. Behavioral development in animals undergoing domestication. Applied Animal Behaviour Science, 65, 245-271. 
Price, E. O. 1984. Behavioral Aspects of Animal Domestication. The Quarterly Review of Biology, 59, 1-32.

Rehkämper, G., Frahm, H. D. \& Cnotka, J. 2008. Mosaic Evolution and Adaptive Brain Component Alteration under Domestication Seen on the Background of Evolutionary Theory. Brain, Behavior and Evolution, 71, 115-126.

Rehkämper, G., Kart, E., Frahm, H. D. \& Werner, C. W. 2003. Discontinuous Variability of Brain Composition among Domestic Chicken Breeds. Brain, Behavior and Evolution, 61, 59-69.

Richter, C. P. 1952. Symposium: Light from animal experimentation on human heredity: 1. Domestication of the norway rat and its implication for the study of genetics in man. American journal of human genetics, 4, 273.

Rosenfeld, J., Van Leeuwen, T., Richards, J. \& Allen, D. 2015. Relationship between growth and standard metabolic rate: measurement artefacts and implications for habitat use and life-history adaptation in salmonids. Journal of Animal Ecology, 84, 4-20.

Schütz, K., Kerje, S., Carlborg, Ö., Jacobsson, L., Andersson, L. \& Jensen, P. 2002. QTL Analysis of a Red Junglefowl $\times$ White Leghorn Intercross Reveals Trade-Off in Resource Allocation Between Behavior and Production Traits. Behavior Genetics, 32, 423-433.

Schütz, K. E. \& Jensen, P. 2001. Effects of Resource Allocation on Behavioural Strategies: A Comparison of Red Junglefowl (Gallus gallus) and Two Domesticated Breeds of Poultry. Ethology, 107, 753-765.

Schütz, K. E., Kerje, S., Jacobsson, L., Forkman, B., Carlborg, Ö., Andersson, L. \& Jensen, P. 2004. Major Growth QTLs in Fowl Are Related to Fearful Behavior: Possible Genetic Links Between Fear Responses and Production Traits in a Red Junglefowl $\times$ White Leghorn Intercross. Behavior Genetics, 34, 121-130.

Sepp, T., Manniste, M., Kaasik, A. \& Horak, P. 2014. Multidimensionality of fear in captive greenfinches (Carduelis chloris). Behavioral Ecology and Sociobiology, 68, 1173-1181.

Smith, B. 2001. Low-Level Food Production. Journal of Archaeological Research, 9, 1-43.

Sossinka, R. 1982. Domestication in birds. Avian biology, 6, 373-403.

Suzuki, K., Ikebuchi, M. \& Okanoya, K. 2013. The impact of domestication on fearfulness: A comparison of tonic immobility reactions in wild and domesticated finches. Behavioural Processes, 100, 58-63.

Tchernov, E. \& Horwitz, L. K. 1991. Body size diminution under domestication: Unconscious selection in primeval domesticates. Journal of Anthropological Archaeology, 10, $54-75$. 
Trut, L., Naumenko, E. \& Belyaev, D. 1972. Change in the pituitary--adrenal function of silverfoxes during selection according to behavior. Soviet genetics.

Trut, L., Oskina, I. \& Kharlamova, A. 2009. Animal evolution during domestication: the domesticated fox as a model. BioEssays, 31, 349-360.

Trut, L. N., Herbeck, Y. E., Kharlamova, A. V., Gulevich, R. G. \& Kukekova, A. V. 2013. Fox domestication: Molecular mechanisms involved in selection for behavior. Russian Journal of Genetics: Applied Research, 3, 419-425.

West, B. \& Zhou, B.-X. 1988. Did chickens go North? New evidence for domestication. Journal of Archaeological Science, 15, 515-533.

Wilkins, A. S., Wrangham, R. W. \& Fitch, W. T. 2014. The "Domestication Syndrome" in Mammals: A Unified Explanation Based on Neural Crest Cell Behavior and Genetics. Genetics, 197, 795-808.

Wohlt, J. E., Allyn, M. E., Zajac, P. K. \& Katz, L. S. 1994. Cortisol Increases in Plasma of Holstein Heifer Calves, from Handling and Method of Electrical Dehorning1. Journal of Dairy Science, 77, 3725-3729.

Voigt, J.-P. \& Fink, H. 2015. Serotonin controlling feeding and satiety. Behavioural Brain Research, 277, 14-31.

Von Holdt, B. M., Pollinger, J. P., Lohmueller, K. E., Han, E., Parker, H. G., Quignon, P., Degenhardt, J. D., Boyko, A. R., Earl, D. A., Auton, A., Reynolds, A., Bryc, K., Brisbin, A., Knowles, J. C., Mosher, D. S., Spady, T. C., Elkahloun, A., Geffen, E., Pilot, M., Jedrzejewski, W., Greco, C., Randi, E., Bannasch, D., Wilton, A., Shearman, J., Musiani, M., Cargill, M., Jones, P. G., Qian, Z., Huang, W., Ding, Z.-L., Zhang, Y.-p., Bustamante, C. D., Ostrander, E. A., Novembre, J. \& Wayne, R. K. 2010. Genome-wide SNP and haplotype analyses reveal a rich history underlying dog domestication. Nature, 464, 898-902.

Väisänen, J., Håkansson, J. \& Jensen, P. 2005. Social interactions in Red Junglefowl $(<\mathrm{i}>$ Gallus gallus $</ \mathrm{i}>$ ) and White Leghorn layers in stable groups and after re-grouping. British Poultry Science, 46, 156 - 168.

Zeder, M. A. \& Hesse, B. 2000. < div xmlns="http://www.w3.org/1999/xhtml"> The Initial Domestication of Goats $(<\mathrm{em}>$ Capra hircus $</ \mathrm{em}>$ ) in the Zagros Mountains 10,000 Years Ago $</$ div $>$. Science, 287, 2254-2257.

Zuidhof, M. J., Schneider, B. L., Carney, V. L., Korver, D. R. \& Robinson, F. E. 2014. Growth, efficiency, and yield of commercial broilers from 1957, 1978, and 2005. Poultry Science.

Zuk, M., Thornhill, R., Ligon, J. D., Johnson, K., Austad, S., Ligon, S. H., Thornhill, N. W. \& Costin, C. 1990. The Role of Male Ornaments and Courtship Behavior in Female Mate Choice of Red Jungle Fowl. The American Naturalist, 136, 459-473. 


\section{Publications}

The articles associated with this thesis have been removed for copyright reasons. For more details about these see:

http://urn.kb.se/resolve?urn=urn:nbn:se:liu:diva-132003 